\title{
Protein Profiles and Dehydrin Accumulation in Some Soybean Varieties (Glycine max L. Merr) in Drought Stress Conditions
}

\author{
Estri Laras Arumingtyas ${ }^{1}$, Evika Sandi Savitri ${ }^{2}$, Runik Dyah Purwoningrahayu ${ }^{3}$ \\ ${ }^{1}$ Biology Department, Faculty of Science, University of Brawijaya, Malang, Indonesia; ${ }^{2}$ Biology Department, Faculty of Science and \\ Technology, Universitas Islam Negeri (UIN) Maulana Malik Ibrahim Malang, Malang, Indonesia; ${ }^{3}$ Research Institute of Legume and \\ Tuber Crops, Malang, Indonesia. \\ Email: laras@ub.ac.id, larasbio@gmail.com
}

Received October $4^{\text {th }}, 2012$; revised November $17^{\text {th }}, 2012$; accepted December $20^{\text {th }}, 2012$

\begin{abstract}
Drought is one of environmental stresses which the most limiting to plant growth and productivity. Drought stress led to a series of changes including biochemical changes like accumulation of osmolit and specific proteins involved in stress tolerance. One of the proteins that play a role in the mechanism of drought resistance is dehydrin protein. This study aimed to identify the protein profiles and dehydrin accumulation in 7 varieties of local Indonesian soybeans: Tanggamus, Nanti, Seulawah and Tidar (tolerant), Wilis and Burangrang (moderate) and Detam-1 (drought stress sensitive). Plants were treated with drought stress by adjusting soil water content to $25 \%$ below field capacity and compared with plants which were grown on normal condition as control plants. The results of SDS-PAGE electrophoresis showed a new protein with the molecular weight of 13 and $52 \mathrm{kDa}$ were induced in Tanggamus, Nanti, Seulawah and Tidar varieties. Western blotting analysis for dehydrin showed that the quantity of the protein in the leaves of all varieties except Tanggamus decreased in drought stress conditions. The quantity of dehydrin protein in tolerant varieties higher than the protein quantity in both moderate varieties and drought sensitive.
\end{abstract}

Keywords: Dehydrin Protein; Drought Stress; Soybean Varieties; LEA

\section{Introduction}

Drought stress led to a series of changes in molecular, biochemistry, physiology and morphology of plants. Biochemical changes include the accumulation of osmolit and specific proteins involved in stress tolerance [1]. Proteins which are synthesized in response to drought stress are called dehydrin (dehydration-induced) and are included in group II late embryogenesis abundant (LEA) proteins $[2,3]$. This protein was reported to have a wide range of molecular weight of $9-200 \mathrm{kDa}$ [3], but most investigation on plant grown under drought stress showed the evidence of dehydrin proteins with molecular weight ranging from $22-60 \mathrm{kDa}$ [4-7]. Close to the $\mathrm{C}$-terminus, dehydrin possess a $\mathrm{K}$-segment which is a conserved, lysine-rich 15-amino acid domain, and near the N-terminus, it has a consensus motif of $\mathrm{Y}$-segment. Dehydrin also usually has an S-segment, a serine residues and $\Phi$ segments which is usually less conserved richpolar amino acids $[8,9]$.

Dehydrin proteins is a functional protein which play a role in the protection against stresses by controlling the bond and the formation of structural proteins (cell mem- brane) and functional proteins (enzymes). These proteins have function in facilitating water retention, membrane stability and ions flow [10-13], and also play a role in the protection of cytoplasms components during drought stress [14] by its ability to bind water molecules on the hydrophilic surface that prevents further damage to cellular proteins [15]. Other proteins that have similar structure with dehydrin, dehydrin-like protein, also have been reported to protect the cell from drying out due to drought stress $[2,16]$. Dehydrin-like proteins may have a role in osmotic adjustment similar to other compounds which has been identified in drought condition such as proline, glycine betaine and sucrose. Another role of this protein is associated with the accumulation of ions in drought stress and control the concentration of the solution in the cytoplasm [16].

The involvement of LEA protein of a molecular weight of $10-30 \mathrm{kDa}$ in the protection of plants from damage caused by drought stress has been reported [17-19]. LEA proteins are expressed at the late stage of seed development [16] and also accumulate in vegetative tissues in response to water shortages [20]. LEA proteins have a 
function to minimize water loss and membrane stability, and to protect against/antidote of reactive oxygen species (ROS) [21].

Dehydrin also suspected to have a role as antioxidative defense directly through the activity of free-radical scavengers [22] or indirectly by binding toxic metals to prevent the production of ROS [23]. Dehydrin prevent the binding of hydroxyl and peroxyl radicals rather than superoxide anion and hydrogen peroxide [22]. Some amino acid residues such as Lysin, Histidin, Glycine and Serrin were assumed to have a link to radical antidote as these residues are modified when dehydrin prevent hydroxyl radicals binding. Dehydrin also reported to protect cellular components from oxidative stress [24].

In Indonesia, soybeans is the main source of nabati protein. However, global climate changing that cause drought stress to plants cause about $50 \%$ lost of soybean production. Many effort has been done to overcome this problem including breeding soybeans for drought tolerance. Indonesia has many local soybean varieties that have potential as germplasm source for breeding purpose. This study aimed to identify the protein profile of Indonesian local soybean varieties under drought stress and to confirm the existence of dehydrin in those varieties in order to characterize the molecular characteristic of soybean germplasm in Indonesia.

\section{Materials and Methods}

\subsection{Plant Material}

Seven soybean varieties were used in this experiment (Table 1).

Those varieties were grown under severe drought stress by applying soil water content of $25 \%$ field capacity at the early growth phase until harvest time, and compared to plant grown in normal condition $(100 \%$ field capacity) as control plants.

\subsection{Materials and Chemical}

The materials used for the isolation of protein and SDSPAGE including: $1 \mathrm{M}$ Tris- $\mathrm{HCl} \mathrm{pH} 8.3,5 \mathrm{M} \mathrm{NaCl}, 1 \mathrm{M}$ DTT, $0.1 \mathrm{M}$ EDTA, aquabidest, $40 \mathrm{mM}$ PMSF, 10\% SDS, Tris- $\mathrm{HCl} \mathrm{pH} 8$, ammonium persulfate (APS), TEMED (Sigma), 12.5\% separating gel, 3\% stacking gel, RSB (Reducing Sample Buffer) for the plant $(0.1 \mathrm{M}$ Tris-CI, 4\% SDS, $0 \%$, 2\% Bromophenol blue, $200 \mathrm{mM}$ DTT), the staining solution (Coomasie Blue R-250, methanol, distilled water, glacial acetic acid), destaining solution (methanol, glacial acetic acid, distilled water).

Materials used for western blotting was $12.5 \%$ separating gel, $3 \%$ stacking gel, RSB for plants $(0.1 \mathrm{M}$ TrisCI, 4\% SDS, 0.2\% Bromophenol blue, $200 \mathrm{mM}$ DTT), PBS-Tween $0 \%, 2 \%, 5 \%$ BSA, primary antibody (antirabbit IgG for plant dehydrin) Abcam, secondary antibody (biotin labelled anti-rabbit IgG), SA-HRP (StreptAvidin-Horseradish Peroxidase), membrane NC (nitrocellulose), TMB substrate, pre-stained protein ladder marker SM-1811 (Fermentas).

\subsection{Isolation of Soybeans Leaves Protein}

Leaves protein was isolated using the method of Stacy and Aalen [25]. Soybean leaves of $0.1 \mathrm{~g}$ was homogenized in $500 \mu \mathrm{L}$ cold extraction buffer. Homogenate then moved into eppendorf tube that has been filled with 250 $\mu \mathrm{L}$ extraction buffer, and then mixed well and added with $40 \mathrm{mM}$ PMSF $25 \mu \mathrm{L}$, incubated for 1 hour in a refrigerator, vortexed every 15 minutes. The mixture then was centrifuged at $13,000 \mathrm{rpm}$, in the temperature of $4^{\circ} \mathrm{C}$ for 5 minutes. The supernatant moved into eppendorf tube. Protein concentration was measured using Nanodrop apparatus.

\subsection{Isolation of Soybeans Seeds Protein}

Seed protein was isolated using the method of Castle and

Table 1. Soybean varieties used in the experiment.

\begin{tabular}{|c|c|c|c|c|c|c|}
\hline No. & Variety & Origin & Seed Colour & Hilum Colour & Yield (ton/ha) & Protein Content $(\%)$ \\
\hline 1. & Tanggamus & Kerinci $\times 3911$ & Yellow & Dark Brown & 1.2 & 44.5 \\
\hline 2. & Nanti & Dempo $\times 3623$ & Yellow & Brown & 1.2 & 42.8 \\
\hline 3. & Seulawah & Wilis $\times 3898$ & Greenish Yellow & Dark Brown & $1.6-2.5$ & 45.9 \\
\hline 4. & Tidar & Mutant B 1682 & Greenish Yellow & Dark Brown & 1.4 & 37.0 \\
\hline 5. & Wilis & Orba $\times 1682$ & Yellow & Dark Brown & 1.6 & 37.0 \\
\hline 6. & Burangrang & Natural crossing & Yellow & Light Brown & $1.6-2.5$ & 39.0 \\
\hline 7. & Detam-1 & $9837 \times$ Kawi & Yellow & n.a & 2.5 & 45.4 \\
\hline
\end{tabular}

n.a : data not available. 
Randall [26]. Soybean seeds crushed into powder with a mortar, $0.1 \mathrm{~g}$ of the powder was taken and added to 10 $\mathrm{ml}$ of extract buffer. Samples were again crushed with a mortar in cold temperatures for 0.5 hours until dissolved. After that, each sample was put into eppendorf tube then centrifuged at $11,000 \mathrm{rpm}$ at $4^{\circ} \mathrm{C}$ for $15 \mathrm{~min}$. Supernatant was taken and put into ependorf. Supernatant was taken and put into ependorf. The pellet was added with 0.067 $\mathrm{M}$ Tris, $2 \%$ SDS and 5\% $\beta$-mercaptoetanol, and extracted for 2 hours, then centrifuged at $11,000 \mathrm{rpm}$ at $4^{\circ} \mathrm{C}$ for 15 min. Supernatant was taken.

\subsection{Sodium Dodecyl Sulphate-Polyacrylamide Gel Electrophoresis (SDS-PAGE)}

The protein resulted from previous step was added with sampel buffer (RSB) with the ratio of $1: 1(10 \mu \mathrm{l}: 10 \mu \mathrm{l})$, then run in SDS-PAGE. The gel use in this experiment was $12 \%$ separating gel and 3\% stacking gel. Electrophoresis was done using a constant current $20 \mathrm{~mA}$ for 4 hours. The gel then stained using Coomassie Brilliant Blue (CBB) and destained. The molecular weight was determined using standards protein.

\subsection{Western Blotting}

Test for the specificity of protein dehydrin was conducted using western blotting method [27], employing a polyclonal antibody antiplant dehydrin. The proteins separated using SDS PAGE was electro transferred onto nitrocellulose (NC) membrane. Transfer was done using 100 volt $300 \mathrm{~mA}$ for 2 hours in the temperature of $4^{\circ} \mathrm{C}$. The membrane containing transferred protein was blocked using BSA solved in PBST for 1 hour, then washed with PBST twice for 5 minutes each, then soaked in an antibody primer dehydrin in BSA overnight. Secondary antibody used in this experiment was IgG biotin solved in TBS. SA-HRP was added after that step. The membrane then washed using PBST 3 times, 5 minutes each. TMB substrate then was added. The reaction was stopped by adding aqua dest.

\section{Results and Discussion}

\subsection{Profile of Leaf Protein Bands in Soybean Varieties under Drought Stress Condition}

The protein profiles of Tanggamus, Nanti, and Seulawah varieties observed at 35 days after planting showed differences between the plant grown in normal (the control) and drought stress conditions (Figure 1). The control plants showed 12 protein bands with molecular weights of $11-200 \mathrm{kDa}$. In drought stress condition new protein bands with molecular weight of $13 \mathrm{kDa}$ and $52 \mathrm{kDa}$ were found in Tanggamus, Nanti, Seulawah and Tidar varieties (Figure 1).
In addition to the emergence of the new protein, there were also found protein bands of different thickness. The thickest the protein bands the more abundant the protein produced.

However the profiles of protein bands produced by drought-sensitive varieties: Wilis, Burangrang and Detam-1 showed no difference between the plants under drought stress and normal water conditions. The profiles of protein on those varieties observed at 35 days after planting in either planting condition consisted of 12 protein bands ranging in molecular weight of $9-200 \mathrm{kDa}$.

\subsection{The Profile of Seed Protein Band of Soybean Varieties in Drought Stress Conditions}

The profile of seed protein observed in the reproductive phase when pods begin to mature were different compared to the protein profile found in the soybean leaves (Figure 2). Less protein bands were observed in the seed. This phenomenon indicated the differences in the expression of genes in the different part of plants.

The profile of seed protein band on varieties that are tolerant to drought stress (Tanggamus, Nanti, Seulawah and Tidar) showed 11 protein bands with molecular weights of 11 - $200 \mathrm{kDa}$. The profiles of seed protein bands possessed by drought tolerant Tanggamus, Nanti, Seulawah and Tidar varieties in stress and control conditions showed no difference with the profile of seed protein band on drought-sensitive varieties, Willis, Burangrang and Detam-1.

\subsection{The Existence of Dehydrin Protein in Soybean Varieties under Drought Stress Condition}

Test for the existence of dehydrin proteins using primary antibody anti-rabbit IgG anti plant dehydrin using Westernblotting method showed that Tanggamus, Nanti, Seulawah and Tidar varieties possess specific bands complementary to dehydrin with the molecular weight of 25 dan $40 \mathrm{kDa}$ (Figure 3). Those bands were present in the stress and control (normal) condition which indicates that dehydrin protein was produced either in stressed or normal condition. This finding is in accordance to the research reported previously [5] that a similar size of dehydrin protein (approximately $78 \mathrm{kDa}$ ) was expressed in both irrigated leaf tissues and drought-stressed tissues in P. bulbosa.

However based on the band thickness showed by all varieties, it was observed that dehydrin protein produced by plants under stress condition thinner than the one in the normal condition. The molecular weight of protein observed by western blotting method were different from the one observed in the SDS-PAGE method which 13 and $52 \mathrm{kDa}$. This may be caused by the nature of SDS- 

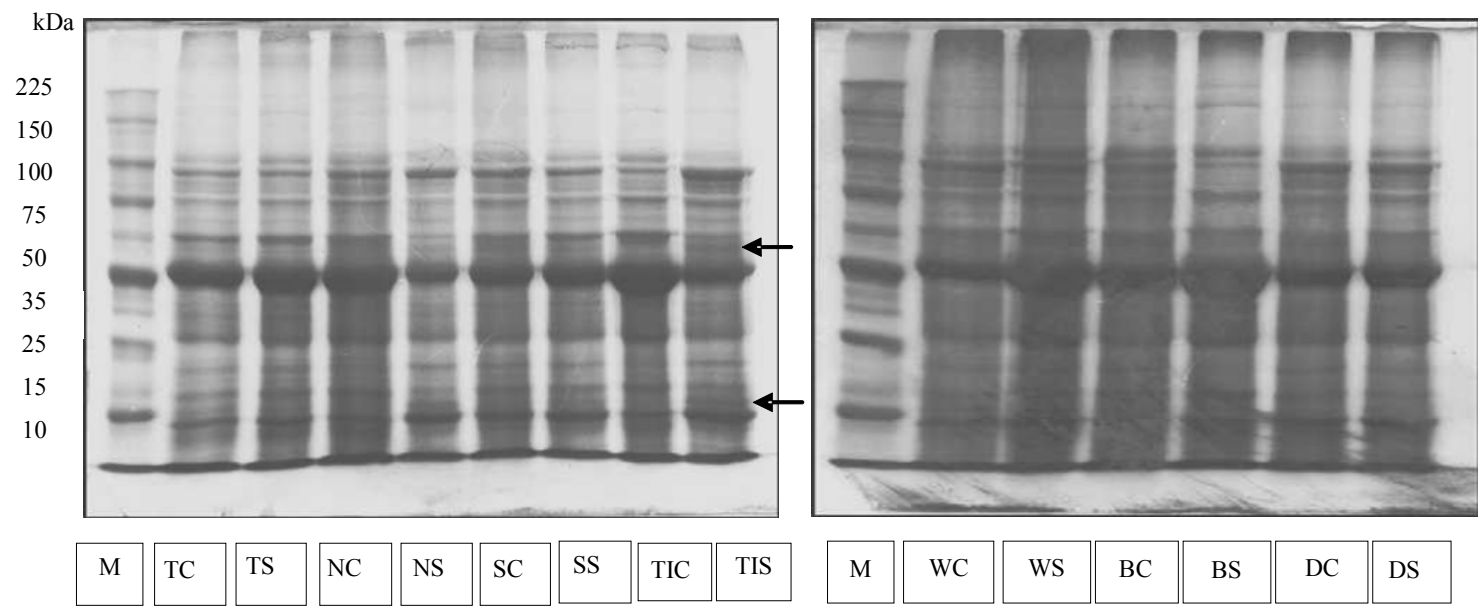

Figure 1. The profile of protein isolated from soybean's leaves at 35 days after planting. $M=$ marker, TC = Tanggamus control, TS $=$ Tanggamus stress, NC $=$ Nanti control, NS $=$ Nanti stress, $\mathrm{SC}=$ Seulawah control, $\mathrm{SS}=\mathrm{Seulawah}$ stress, $\mathrm{TC}=\mathrm{Ti}-$ dar control, TS $=$ Tidar stress, WC $=$ Wilis control, $\mathbf{W S}=$ Willis stress, $\mathrm{BC}=$ Burangrang control, $\mathrm{BS}=$ Burangrang stress, DC $=$ Detam-1 control, DS $=$ Detam-1 stress. Arrows show the new type of protein.
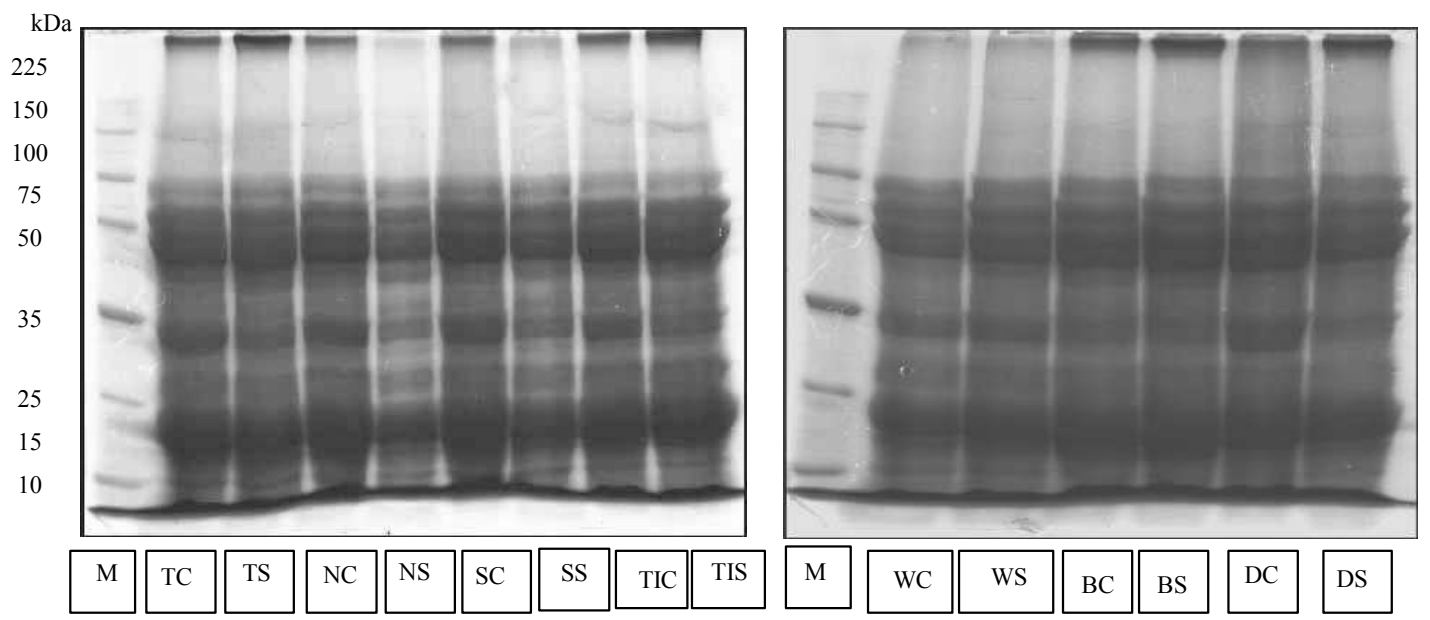

Figure 2. The profile of protein isolated from soybean's seed. $M=$ marker, $\mathbf{T C}=$ Tanggamus control, $\mathrm{TS}=$ Tanggamus stress, NC $=$ Nanti control, NS $=$ Nanti stress, SC $=$ Seulawah control, SS $=$ Seulawah stress, TC $=$ Tidar control, TS $=$ Tidar stress, WC $=$ Wilis control, $\mathbf{W S}=$ Willis stress, $\mathrm{BC}=$ Burangrang control, $\mathrm{BS}=$ Burangrang stress, $\mathbf{D C}=\mathrm{Detam}-1 \mathrm{control}, \mathrm{DS}=\mathrm{De}-$ tam-1 stress.

PAGE method which denatured the protein during the process. So, the protein observed in SDS-PAGE is polypeptides which may be part of the complete functional protein.

Comparing the quantity of dehydrin protein among the tolerant varieties showed that each variety demonstrate different quantity of dehydrin protein (Figure 4).

Generally, the quantity of dehydrin protein in the plant under stress conditions was lower compared to the control condition, except for Tanggamus. The low quantity of dehydrin observed was in accordance to the result of western blotting analysis which showed that plants grown under stress condition had thinner protein bands than the plants grown in normal condition. When the phenomenon showed by Tanggamus varieties was typical, and in conformity to the general theory and observation that drought stress cause the increase of accumulation of dehydrin $[2,3,13,18,22,24]$, yet, the phenomenon showed by the other varieties were contradictory i.e. severe drought stresses caused the decrease of dehydrin accumulation. However similar evidence also has been reported [28].

It has been reported that lower accumulation of dehydrin-like proteins in seedlings under stress was predicted to be the effect of the greater accumulation of $\mathrm{H}_{2} \mathrm{O}_{2}$ induced by the stress, which lead to the increase of oxidative damaged under water stress [28]. Dehydrins have been reported to have radical scavenging activity and 


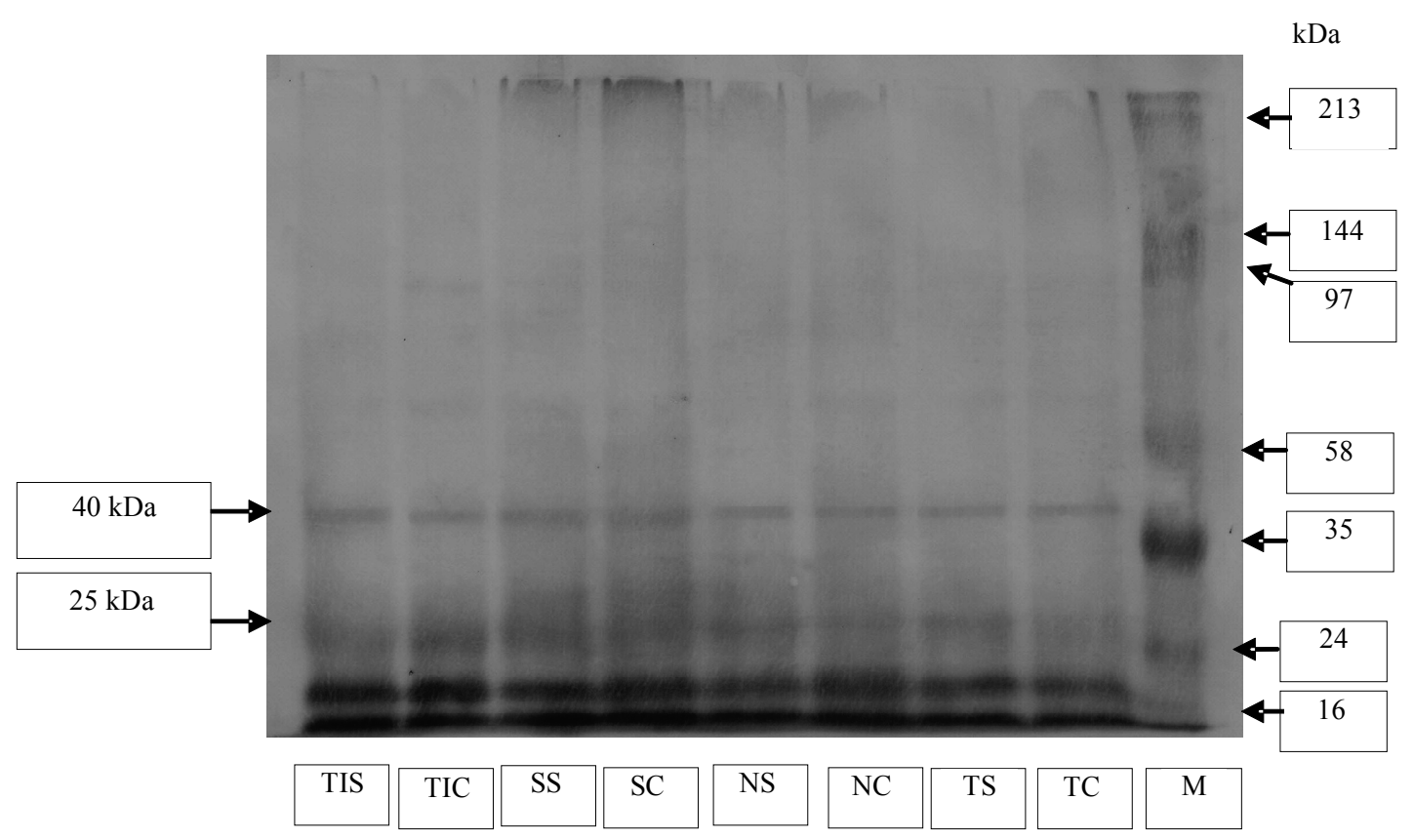

Figure 3. Dehydrin antibody specificity test with dehydrin Westernblot method on soybean plants. TC = Tanggamus control, TS $=$ Tanggamus stress, NC = Nanti control, NS $=$ Nanti stress, SC $=$ Seulawah control, SS $=$ Seulawah stress, TC $=$ Tidar control, $\mathbf{T S}=$ Tidar stress.

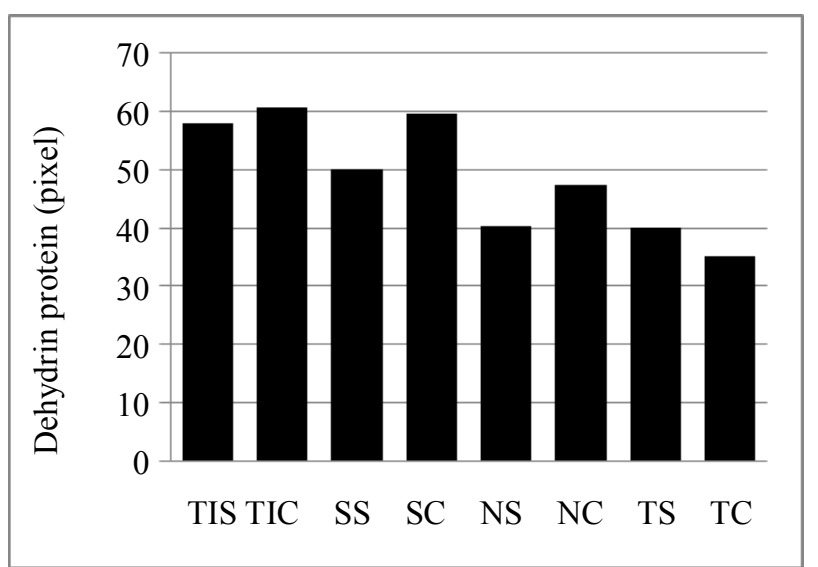

Figure 4. The quantity of Dehydrin protein in soybean varieties. TC $=$ Tanggamus control, TS $=$ Tanggamus stress, NC = Nanti control, NS = Nanti stress, $S C=$ Seulawah control, SS $=$ Seulawah stress, TC $=$ Tidar control, TS $=$ Tidar stress.

inhibitory activity against lipid peroxidation. Dehydrins like CuCOR19 may possibly oxidized by radicals like hydroxyl and peroxyl radicals, so they could reduce radicals and in turn lessen oxidative damages induced by water stress [22]. However exceeding hydroxyl radicals induced by a high level of $\mathrm{H}_{2} \mathrm{O}_{2}$ may cause excessive degradation of dehydrins, and result in low levels of dehydrins [22].

The decrease of dehydrin accumulation in response to drought stress was also found in drought-sensitive varie- ties Wilis, Burangrang and Detam-1. Those varieties showed specific bands of dehydrin protein with the molecular weight of 25 and $40 \mathrm{kDa}$ either in the drought stress condition and normal condition (Figure 5).

All varieties showed thinner dehydrin protein bands in stress condition compared to the one in the normal condition. This result was confirmed by the result of quantification of dehydrin protein of all soybean varieties in both conditions (Figure 6). The plant grown in drought stress condition produced lower quantity dehydrin protein compared to the one grown in normal condition.

Other than the decrease of a certain protein accumulation, lost of certain protein was also reported [29]. This indicates that in drought stress, some protein increase in the quantity but some other was decrease or missing. The differences in the plant responses to drought stress indicates that there is many mechanism used by plants to survive drought stress [30]. It has also been investigated that genetically the nature of tolerance against drought stress is controlled by many factors [31,32].

Generally, the quantity of dehydrin protein produced by tolerant varieties Tanggamus, Nanti, Seulawah and Tidar higher compared to the sensitive varieties Wilis, Burangrang and Detam-1. Tolerant varieties seem capable in maintaining protein for defending against drought stress compared to the sensitive varieties. In this experiment, drought stress given to the both group of varieties (tolerant and sensitive) cause the decrease of production or accumulation of dehydrin protein as has 


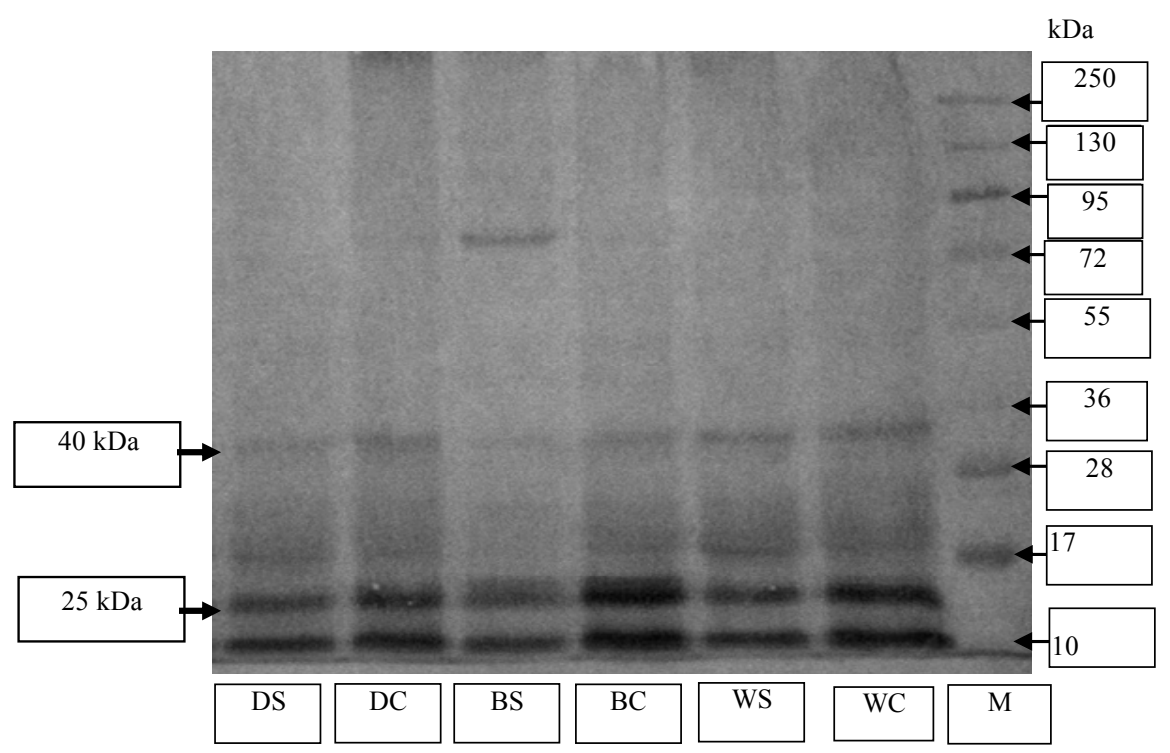

Figure 5. Dehydrin antibody specificity test with dehydrin Westernblot method on soybean plants. $M=$ Marker, WC $=$ Wilis control, WS $=$ Willis stress, BC $=$ Burangrang control, BS $=$ Burangrang stress, DC $=$ Detam-1 control, DS $=$ Detam-1 stress .

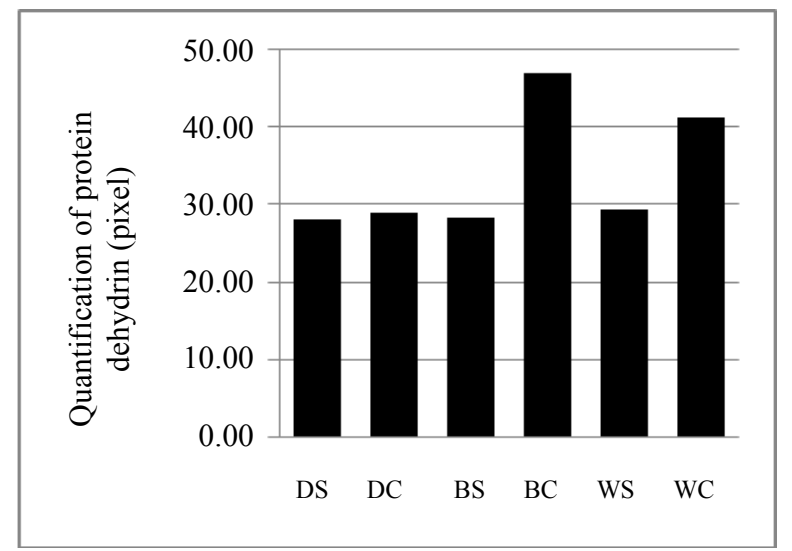

Figure 6. Quantification of protein in soybean dehydrin. WC $=$ Wilis control, WS $=$ Wilis stress, $\mathbf{B C}=$ Burangrang control, $\mathrm{BS}=$ Burangrang stress, $\mathrm{DC}=$ Detam -1 control, $\mathrm{DS}$ = Detam -1 stress.

been reported in other research [3]. However the production or accumulation of that protein was higher in the tolerant varieties compared to the sensitive varieties. This indicates that tolerance to drought stress was among others, controlled by the amount of dehydrin accumulated during the stress as has been reported in some experiment in plants $[4,7,33]$. Several transgenic plants shows overexpression of the gene codes dehydrin synthesis [34-37].

Since proteins are the basic compound which are important to support all cell function [38], maintenance of protein concentration in the cell is very important for the continuity of cell life [39-41]. The protein's concentration depends on the expression of gene responsible for the synthesis of those proteins. Moreover protein varia- tion, including the amount or the type has been reported as an important part of plant response to environmental stress and plant adaptation mechanisme to certain environments $[42,43]$.

\section{Conclusion}

The protein profile of different part of drought-tolerant and drought sensitive plants used in this experiment were different. The profile of leaf's protein of drought-sensitive varieties was not change under stress condition, whereas changes were shown by drought-tolerant varieties. Severe drought stress causes the decrease of dehydrin protein accumulation in most varieties, except for the Tanggamus which is tolerant variety.

\section{Acknowledgements}

We are grateful to the Research Institute of Legumes and Tuber Crops, Kendalpayak, Malang, Indonesia, for providing soybeans seeds. The research was supported by the Directorate General of Higher Education (DGHE)'s PHB project, Indonesia.

\section{REFERENCES}

[1] K. Shinozaki and K. Yamaguchi-Shinozaki, "Gene Networks Involved in Drought Stress Response and Tolerance," Journal of Experimental Botany, Vol. 58, No. 2, 2007, pp. 221-227. doi:10.1093/jxb/erl164

[2] T. J. Close and P. M. Chandler, "Cereal Dehydrins: Serology, Gene Mapping and Potential Functional Roles," Australian Journal of Plant Physiology, Vol. 17, No. 3, 1990, pp. 333-344. doi:10.1071/PP9900333 
[3] T. J. Close, "Dehydrin: Emergence of a Biochemical Role of a Family of Plant Dehydration Proteins," Physiology of Plant, Vol. 97, No. 4, 1996, pp. 795-803. doi:10.1111/i.1399-3054.1996.tb00546.x

[4] C. G. Lopez, G. M. Banowetz, C. J. Peterson and W. E. Kronstad, "Differential Accumulation of a 24-kd Dehydrin Protein in Wheat Seedlings Correlates with Drought Stress Tolerance at Grain Filling," Hereditas, Vol. 135, No. 2-3, 2001, pp. 175-181. doi:10.1111/j.1601-5223.2001.00175.x

[5] F. Volaire, C. Genevieve and L. Francois, "Drought Survival and Dehydration Tolerance in Dactylis glomerata and Poa bulbosa," Australian Journal of Plant Physiology, Vol. 28, No. 8, 2001, pp. 743-754.

[6] Y. Jiang and B. Huang, "Protein Alterations in Response to Water Stress and ABA in Tall fescue," Crop Science, Vol. 42, No. 1, 2002, pp. 202-207. doi:10.2135/cropsci2002.0202

[7] C. G. Lopez, G. M. Banowetz, C. J. Peterson and W. E. Kronstad, "Wheat Dehydrin Accumulation in Response to Drought Stress during Anthesis," Plant Signaling and Behaviour, Vol. 29, No. 12, 2002, pp. 1417-1425.

[8] C. R. Allagulova, F. R. Gimalov, F. M. Shakirova and V. A. Vakhitov, "The Plant Dehydrins: Structure and Putative Functions," Biochemistry (Moscow), Vol. 68, No. 9, 2003, pp. 945-951. doi:10.1023/A:1026077825584

[9] M. Hanin, F. Brini, C. Ebel, Y. Toda, S. Takeda and K. Masmoudi, "Plant Dehydrins and Stress Tolerance: Versatile Proteins for Complex Mechanisms," Plant Signalling Behaviour, Vol. 6, No. 10, 2011, pp. 1503-1509. doi:10.4161/psb.6.10.17088

[10] L. Dure III, "Structural Motif in Lea Proteins," In: T. J. Close and E. A. Bray, Eds., Plant Response to Cellular Dehydration during Environmental Stress, Current Topics in Plant Physiology, Vol. 10, American Society of Plant Physiologists, Rockville, 1993, pp. 91-103.

[11] T. J. Close, R. D. Fenton and F. Moonan, "A View of Plant Dehydrins Using Antibodies Specific to the Carboxy Terminal Peptide," Plant Molecular Biology, Vol. 23, No. 2, 1993, pp. 279-286. doi:10.1007/BF00029004

[12] E. A. Bray, "Plant Responses to Water Deficit," Trends in Plant Science, Vol. 2, No. 2, 1997, pp. 48-54. doi:10.1016/S1360-1385(97)82562-9

[13] E. G. Beck, S. Fettig, C. Knake, K. Gartig and T. Bhattarai, "Specific and Unspecific Responses of Plant to Cold and Drought Stress," Journal of Bioscience, Vol. 32, No. 3, 2007, pp. 501-510. doi:10.1007/s12038-007-0049-5

[14] S. A. Blackman, R. L. Obendorf and A. C. Leopold, "Desiccation Tolerancein Developing Soybean Seeds: The Role of Stress Proteins," Physiologia Plantarum, Vol. 93, No. 4, 1995, pp. 630-638. doi:10.1111/j.1399-3054.1995.tb05110.x

[15] T. J. Close, "Dehydrins: A Commonalty in the Response of Plants to Dehydration and Low Temperature," Physiologia Plantarum, Vol. 97, No. 4, 1997, pp. 795-803. doi:10.1111/i.1399-3054.1996.tb00546.x
[16] L. III Dure, M. Crouch, J. Harada, T. H. D. Ho, J. Mundy, R. Quatrano, T. Thomas and Z. R. Sung, "Common Amino Acid Sequence Domains among the LEA Proteins of Higher Plants," Plant Molecular Biology, Vol. 12, No. 5, 1989, pp. 475-486. doi:10.1007/BF00036962

[17] B. Hong, R. Barg and D. H. Ho, "Development and Organ-Specific Expression of an ABA- and Stress-Induced Protein in Barley," Plant Molecular Biology, Vol. 18, No. 4, 2005, pp. 663-674. doi:10.1007/BF00020009

[18] N. H. Samarah, R. E. Mullen, S. R. Cianzio and P. Scott, "Dehydrin-Like Protein in Soybean Seeds in Response to Drought Stress during Seed Filling," Crop Science, Vol. 46, No. 5, 2006, pp. 2141-2150. doi:10.2135/cropsci2006.02.0066

[19] K. Demirevska, L. Simova-Stoilova, V. Vassileva, I. Vaseva, B. Grigorova and U. Feller, "Drought Induced Leaf Protein Alterations in Sensitive and Tolerant Wheat Varieties," General and Applied Plant Physiology Special Issue, Vol. 34, No. 1-2, 2008, pp. 79-102.

[20] E. A. Bray, "Plants Responses to Water Deficit," Trends in Plant Science, Vol. 2, No. 2, 2000, pp. 48-54. doi:10.1016/S1360-1385(97)82562-9

[21] M. Nylander, J. Svensson, E. T. Palva and B. V. Welin, "Stress Induced Accumulation and Tissue Spesific Localization of Dehydrin in Arabidopsis thaliana," Plant Molecular Biology, Vol. 45, No. 3, 2001, pp. 263-279. doi:10.1023/A:1006469128280

[22] M. Hara, M. Fujinaga and T. Kuboi, "Radical Scavenging Activity and Oxidative Modification of Citrus Dehydrin," Plant Physiology and Biochemistry, Vol. 42, No. 7-8, 2004, pp. 657-662. doi:10.1016/j.plaphy.2004.06.004

[23] M. Hara, M. Fujigana and T. Kuboi, "Metal Binding by Citrus Dehydrin with Histidine-Rich Domains," Journal of Experimental Botany, Vol. 56, No. 420, 2005, pp. 2695 2703. doi: $10.1093 / \mathrm{jxb} /$ eri262

[24] M. Hara, "The Multifunctionality of Dehydrins. An Overview," Plant Signaling and Behaviour, Vol. 5, No. 5, 2009, pp. 503-508.

[25] R. Stacy and R. Aalen, "Isolation of Total Protein," 2003. $\mathrm{http} / /$ biology.u10.no/molbiol/protocol/protein.htm

[26] S. L. Castle and P. J. Randall, "Effects of Sulfur Deficiency on the Synthesis and Accumulation of Proteins in the Developing Wheat Seed," Australian Journal of Plant Physiology, Vol. 14, No. 5, 1987, pp. 503-516. doi:10.1071/PP9870503

[27] H. Towbin, T. Staehelin and J. Gordon, "Electrophoretic Transfer of Proteins from Polyacrylamide Gels to Nitrocellulose Sheets: Procedure and Some Applications," Proceeding of the National Academy of Sciences USA, Vol. 76, No. 9, 1979, pp. 4350-4354.

[28] X. Sun, S. Yuan and H. H. Lin, "Salicylic Acid Decreases the Levels of Dehydrin-Like Proteins in Tibetan Hulless Barley Leaves under Water Stress," Verlag der Zeitschrift für Naturforschung, Vol. 61c, No. 3-4, 2006, pp. $245-$ 250.

[29] N. Mohammadkhani and R. Heidari, "Effect of Drought on Soluble Protein in Two Maize Varieties," Turkish 
Journal of Biology, No. 32, 2008, pp. 23-30.

[30] P. E. Verslues, M. Agarwal, S. Katiyar-Agarwal, J. Zhu and J. K. Zhu, "Techniques For Molecular Analysis: Methods and Concepts in Quantifying Resistance to Drought, Salt and Freezing, Abiotic Stresses That Affect Plant Water Status," The Plant Journal, Vol. 45, No. 4, 2006, pp. 523-539. doi:10.1111/j.1365-313X.2005.02593.x

[31] G. M. Pastori and C. H. Foyer, "Common Components, Networks, and Pathways of Cross-Tolerance to Stress. The Central Role of 'Redox' and Abscisic Acid-Mediated," Plant Physiology, Vol. 129, No. 2, 2002, pp. 460468. doi:10.1104/pp.011021

[32] E. L. Arumingtyas, W. Widoretno and S. Indriyani, "Somaclonal Variations of Soybeans (Glycine Max. L. Merr) Stimulated by Drought Stress Based on Random Amplified Polymorphic DNAs (RAPDs)," American Journal of Molecular Biology, Vol. 2, No. 1, 2012, pp. 85-91. doi:10.4236/ajmb.2012.21009

[33] Z. N. Ozturk, V. Talame, M. Deyholos, C. B. Michalowski, D. W. Galbraith, N. Gozukirmizi, R. Tuberosa and H. J. Bohnert, "Monitoringl Arge-Scale Changes in Transcript Abundance in Drought-And Salt-Stressed Barley," Plant Molecular Biology, Vol. 48, No. 5-6, 2002, pp. 551-573. doi:10.1023/A:1014875215580

[34] T. Puhakainen, M. W. Hess, P. M. Kela, J. Svensson, P. Heino and E. T. Palva, "Overexpression of Multiple Dehydrin Genes Enhances Tolerance to Freezing," Plant Molecular Biology, Vol. 54, No. 5, 2004, pp. 743-753. doi:10.1023/B:PLAN.0000040903.66496.a4

[35] Y. Peng, J. L. Reyes, H. Wei, Y. Yang, D. Karlson, A. A. Covarrubias, S. L. Krebs, A. Fessehaie and R. Arora, "RcDhn5, a Cold Acclimation-Responsive Dehydrin from Rhododendron Catawbiense Rescues Enzyme Activity from Dehydration Effects in Vitro and Enhances Freezing Tolerance in RcDhn5-Overexpressing Arabidopsis Plants," Physiologia Plantarum, Vol. 134, No. 4, 2008, pp. 583597. doi:10.1111/j.1399-3054.2008.01164.x

[36] U. K. S. Shekhawat, L. Srinivas and T. R. Ganapathi,
"MusaDHN-1, a Novel Multiple Stress-Inducible SK3Type Dehydrin Gene, Contributes Affirmatively to Droughtand Salt-Stress Tolerance in Banana," Planta, Vol. 234, No. 5, 2011, pp. 915-932. doi:10.1007/s00425-011-1455-3

[37] A. E. Ochoa-Alfaro, M. Rodríguez-Kessler, M. B. PérezMorales, P. Delgado-Sánchez, C. L. Cuevas-Velazquez, G. Gómez-Anduro and J. F. Jiménez-Bremont, "Functional Characterization of an Acidic SK3 Dehydrin Isolated from an Opuntia streptacantha cDNA Library," Planta, Vol. 235, No. 3, 2012, pp. 565-578. doi:10.1007/s00425-011-1531-8

[38] K. Dose, "Biochemic," Springer, Berlin, Heidelberg, New York, 1980. doi:10.1007/978-3-642-96536-4

[39] M. Pierre and A. Savoure, "Effect of Water Stress and $\mathrm{SO}_{2}$ Pollution on Spruce Endopeptides," Plant Physiology and Biochemistry, Vol. 28, No. 1, 1990, pp. 95-104.

[40] H. Roy-Macauley, Y. Zuily-Fodil, M. Kidric, A. T. Pham Thi and J. Viera da Silva, "Effect of Drought Stress on Proteolytic Activitas in Phaseolus and Vigna Leaves from Sensitive and Resistant Plants," Physiologia Plantarum, Vol. 85, No. 1, 1992, pp. 90-96. doi:10.1111/j.1399-3054.1992.tb05268.x

[41] G. Singh and V. K. Rai, "Responses of Two Differentially Sensitive Cicer arietinum L. Cultivars to Water Stress Protein Content and Drought Resistance," Biologia Plantarum, Vol. 24, No. 1, 1982, pp. 7-12. doi:10.1007/BF02898474

[42] R. D. Viestra, "Protein Degradation in Plants," Annual Review of Plant Physiology and Plant Molecular Biology, Vol. 44, 1993, pp. 385-410. doi:10.1146/annurev.pp.44.060193.002125

[43] B. Hieng, K. Ugrinovich, J. Sustar-Vozlich and M. Kidric, "Different Classes o Proteases are Involved in the Response to Drought of Phaseolus vulgaris L. Cultivars Differing in Sensitivity," Journal of Plant Physiology, Vol. 161, No. 5, 2004, pp. 519-530. doi:10.1078/0176-1617-00956 